\title{
Tree growth and soil fertility in plantations of genetic materials of Eucalyptus spp.
}

\author{
Crescimento das árvores e fertilidade do solo em materiais genéticos de Eucalyptus spp. \\ Crecimiento de árboles y fertilidad del suelo en materiales genéticos de Eucalyptus spp.
}

Received: 03/09/2021 | Reviewed: 03/17/2021 | Accept: 03/21/2021 | Published: 03/29/2021

Eleandro José Brun

ORCID: https://orcid.org/0000-0003-3832-1320 Federal University of Technology Parana, Brazil E-mail: eleandrobrun@utfpr.edu.br

Diego Maicon Scheis

ORCID: https://orcid.org/0000-0002-5750-1522 Federal University of Technology Parana, Brazil E-mail: florestaldiego@hotmail.com

Maurício Romero Gorenstein

ORCID: https://orcid.org/0000-0003-3181-1669 Federal University of Technology Parana, Brazil E-mail: mauriciorg@utfpr.edu.br

Flávia Gizele Konig Brun

ORCID: https://orcid.org/0000-0002-4268-6763 Federal University of Technology Parana, Brazil

E-mail: flaviag@utfpr.edu.br

Evandro Alcir Meyer

ORCID: https://orcid.org/0000-0003-4581-7690 Federal University of Santa Maria, Brazil

E-mail: eam.meyer@gmail.com

Solon Jonas Longhi

ORCID: https://orcid.org/0000-0002-5701-2139 Federal University of Santa Maria, Brazil E-mail: longhi.solon@gmail.com

Joseane Aparecida Derengoski

ORCID: https://orcid.org/0000-0003-0476-2187 Federal University of Technology Parana, Brazil E-mail: derengoski.josi@gmail.com

Luan Luchese

ORCID: https://orcid.org/0000-0002-6009-1560 Federal University of Technology Parana, Brazil E-mail: luan_luchese@hotmail.com

Bruno Leite dos Santos

ORCID: https://orcid.org/0000-0002-8932-0064 Federal University of Technology Parana, Brazil E-mail: engflorestal.bruno@gmail.com

\begin{abstract}
Were analyzed the growth and the relationship with soil fertility of genetic materials of Eucalyptus spp. planted in a non-traditional eucalyptus forestry region in Brazil. Five genetic materials were selected, two seminal: Eucalyptus urophylla and E. pellita and three clones: GFMO27, I224, and H13, planted in experimental plots in a completely randomized design. The diameter at breast height $(\mathrm{DBH})$ and total height were measured; basal area and dendrometric variables were calculated, for the ages $24,36,48,60,72$, and 108 months, both statistically compared. The soil was chemically characterized at 108 months of age and correlated with dendrometric variables. The growth of clones H13, I224, and GFMO 27 were superior to the E. pellita and E. urophylla. The levels of $\mathrm{N}$ and MO had a significant correlation with the volume and the $\mathrm{Al}^{+3}$ showed a positive correlation with $\mathrm{DBH}$. Clone $\mathrm{H} 13$ showed higher values than the other materials, in all variables analyzed, reaching an individual volume of $1.27 \mathrm{~m}^{3}$ at 108 months. The other genetic materials (GFMO27, I244, and E. urophylla) proved to be variable in their growth behavior at different ages, and E. pellita had lower growth. The recommended genetic materials for planting are H13 and E. urophylla.
\end{abstract}

Keywords: Planted forest; Forest soil; Forest genetic improvement; Soil organic matter.

\section{Resumo}

Avaliou-se o crescimento e a relação com a fertilidade do solo de materiais genéticos de Eucalyptus spp. plantados em região não tradicional de silvicultura de eucalipto no Brasil. Entre os vários em estudo, foram selecionados cinco materiais genéticos, dois seminais: Eucalyptus urophylla e E. pellita e três clones: GFMO27, I224 e H13, plantados em talhões experimentais em espaçamento de $3 \mathrm{~m} \mathrm{x} 2 \mathrm{~m}$, em delineamento inteiramente casualizado. Foram mensurados o 
diâmetro à altura do peito (DAP), a altura total e calculada a área basal e o volume para as idades de 24, 36, 48, 60, 72 e 108 meses, com os materiais genéticos sendo comparados estatisticamente entre si. O solo dos talhões foi caracterizado quimicamente aos 108 meses de idade quanto à matéria orgânica $(\mathrm{MO})$, macronutrientes, alumínio $(\mathrm{Al})$ e pH e correlacionados com DAP, área basal, altura total, volume do tronco, altura comercial e área de copa. O crescimento dos clones H13, I224 e GFMO 27 foi superior às espécies E. pellita e E. urophylla. Os teores de N e MO tiveram correlação significativa com volume de madeira e o teor de Al+3 apresentou correlação positiva com DAP. O clone H13 apresentou valores superiores aos demais materiais, em todas as variáveis analisadas, alcançando um volume individual de $1,27 \mathrm{~m}^{3}$ aos 108 meses. Os demais materiais genéticos (GFMO27, I244 e E. urophylla) mostraram-se variáveis em seu comportamento de crescimento nas diferentes idades e o E. pellita teve crescimento inferior. O solo da área apresenta carência de diversos elementos químicos, os quais encontram-se em níveis baixos. Os materiais genéticos recomendados para plantio são o clone H13 e o E. urophylla.

Palavras-chave: Floresta plantada; Solo florestal; Melhoramento genético florestal; Matéria orgânica do solo.

\section{Resumen}

El crecimiento y la relación con la fertilidad del suelo de materiales genéticos de Eucalyptus spp. plantado en una región forestal de eucalipto no tradicional en Brasil. Entre los varios en estudio, se seleccionaron cinco materiales genéticos, dos seminales: Eucalyptus urophylla y E. pellita y tres clones: GFMO27, I224 y H13, plantados en parcelas experimentales espaciadas $3 \mathrm{~m} \mathrm{x} 2 \mathrm{~m}$, en un diseño completamente aleatorizado. Se midió el diámetro a la altura del pecho (DAP), la altura total y se calculó el área basal y el volumen para las edades de 24, 36, 48, 60, 72 y 108 meses, comparándose estadísticamente los materiales genéticos entre sí. El suelo de las parcelas se caracterizó químicamente a los 108 meses de edad en términos de materia orgánica (MO), macronutrientes, aluminio (Al) y pH y se correlacionó con DAP, área basal, altura total, volumen de tronco, altura comercial y área de la copa. El crecimiento de los clones H13, I224 y GFMO 27 fue superior al de las especies E. pellita y E. urophylla. Los niveles de N y MO tuvieron una correlación significativa con el volumen de madera y el contenido de $\mathrm{Al}^{+3}$ mostró una correlación positiva con DAP. El clon H13 mostró valores superiores a los demás materiales, en todas las variables analizadas, alcanzando un volumen individual de 1,27 $\mathrm{m}^{3}$ a los 108 meses. Los otros materiales genéticos (GFMO27, I244 y E. urophylla) demostraron ser variables en su comportamiento de crecimiento a diferentes edades y E. pellita tuvo un crecimiento menor. El suelo de la zona carece de varios elementos químicos, que se encuentran en niveles bajos. Los materiales genéticos recomendados para plantar son el clon $\mathrm{H} 13$ y E. urophylla.

Palabras clave: Bosque plantado; Suelo forestal; Mejoramiento genético forestal; Materia orgánica del suelo.

\section{Introduction}

The genus Eucalyptus, native to Australia, found in Brazil the ideal edaphoclimatic conditions for its development, causing it to show greater growth in height and diameter and, consequently, greater productivity in a shorter period than in other countries (Schumacher \& Viera, 2015). The high productivity of eucalyptus in Brazil is due to the adoption of silviculture and consolidated management practices, genetic improvement, and the edaphoclimatic conditions of the country (Ibá, 2020). The area of eucalyptus planted forests in Brazil, in 2019, reached 6.97 million hectares, which represents $77 \%$ of the total area

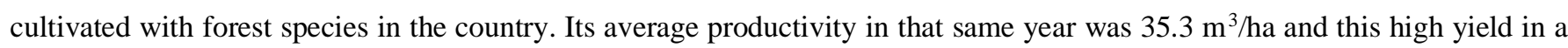
volume of wood produced, combined with one of the fastest production and harvest cycles in the world, has given Brazil worldwide recognition for its high productivity (Ibá, 2020).

The advancement of research in genetic improvement and eucalyptus silviculture has brought a range of clones and hybrids of high productivity and with a diversified application of wood. As a result, large producing regions have become increasingly productive in supplying the national and, especially, international markets, with high productivity and lower production costs (Assis, et al., 2015).

In forest plantations, some aspects must be taken into account as they directly influence the absorption of nutrients, plant development, and biomass production, involving the characteristics of the site and planting. The site encompasses all the characteristics of the soil, from natural fertility, preparation, fertilization, and correct orientation of the planting bands about the best solar incidence. Regarding planting, the quality of the seedling or the correct choice of the appropriate genotype for that climatic zoning, are essential for good productivity (Wink, et al., 2018).

Concerning climatic factors in the southern region of Brazil, frost considerably restricts the possibility of reforestation with eucalyptus, as there are few commercial materials for cold regions; most are adapted to tropical conditions and are not 
tolerant to frost (Higa \& Wrege, 2010). This explains, in large part, the small percentage of area planted with the species in Paraná, which appears in sixth place in the ranking of area planted with eucalyptus (4\%), with pine being still the most planted forest species in the state, which is the largest producer in the country (Ibá, 2020).

Eucalyptus plantations in Brazil have a history of cultivation in areas of low natural fertility (Pincelli, et al., 2014). For this reason, carrying out mineral fertilization in new forest stands is extremely necessary for the good initial development of eucalyptus, especially when the previous soil analysis has already demonstrated low fertility (Serpe, et al., 2018). Thus, studies that assess the relationship between regional edaphoclimatic conditions and the genetic materials available on the market are essential for determining which the best materials to be explored are.

Besides, given of potential productivity and the growing demand for forest products, areas with planted forests have expanded to non-traditional regions in Brazil. These regions demand research information on which genetic materials are more adapted and will have better productivity in them.

In this study, the growth and adaptation of different genetic materials of Eucalyptus spp. the soil fertility conditions prevailing in a non-traditional region in eucalyptus silviculture in Brazil, Southwest Paraná, based on the analysis of dendrometric variables at different ages and its relationship with the chemical quality of the soil.

\section{Material and Methods}

The study was carried out with field research, with the comparison of qualitative treatments (genetic materials of Eucalyptus) with the use of continuous variables (dendrometric and edaphic). This study is based on guidelines such as from Imanã-Encinas \& Santana (2019) and others researchers in Forest Science.

\section{Characterization of the study area}

The study was carried out at the Federal University of Technology - Parana (UTFPR), Campus Dois Vizinhos, in the southwest region of Paraná, where the experimental plots with genetic materials of Eucalyptus ssp. was installed in December/2009. The Dois Vizinhos city has an average altitude of $509 \mathrm{~m}$, a Cfa, a subtropical climate with well-distributed rainfall during the summer, an average annual rainfall of $2025 \mathrm{~mm}$, and hot summers, with an average annual temperature of $19^{\circ}$ C (Alvarez, et al., 2013).

The relief of the region consists of plateaus with average altitudes of $500 \mathrm{~m}$. The soil of the experimental area is classified as typical Red Dystrophic Nitisol. These are deep or moderately deep, well-drained, with a clayey or very clayey texture along with the profile and reduced textural gradient. They are soils with good physical conditions and have low base saturation as a limitation and, in the case of wavy relief, susceptibility to erosion (Embrapa, 2018).

The study area had a history of use with an annual crop, in the regular and late growing season, in a conventional system, with mechanized practices of soil preparation and planting, application of herbicides, and chemical fertilizers. For the implantation of the study, three months before planting, the control of leaf-cutting ants in the area and its surroundings were carried out, using granulated baits at a dosage of $10 \mathrm{~g} / \mathrm{m}^{2}$ or per scout, depending on the level of anthill occurrence. The area received a mechanized clearing aimed at crushing cultural remains and spontaneous vegetation. After 15 days of mowing, when the vegetation regrowth, the systemic herbicide of full action was applied, in the dosage of $3 \mathrm{~L} / \mathrm{ha}$, in the whole area. The soil preparation was carried out at a level, in a minimum cultivation system, with mechanical scarification in the planting line up to about $30 \mathrm{~cm}$ in depth. The soil preparation was carried out at a level, in a minimum cultivation system, with mechanical scarification in the planting line up to about $30 \mathrm{~cm}$ in depth.

The seedlings from tubes were planted manually, and the genetic materials were planted in separate plots. Fertilization was carried out based on soil analysis, one month after planting, with $360 \mathrm{~g}$ of NPK (6-30-6) in a lateral trough system. As a 
driving measure, the control of leaf-cutting ants, mowing between the lines, and manual crowns around the plants was carried out. At 2 years of age, pruning was carried out on plants up to $50 \%$ of the total height, using a saw.

For the study, five genetic materials of Eucalyptus spp. (species, clones, or hybrids) from clonal seedlings of the Experimental Forest Science Station of Itatinga-SP (ESALQ/USP), composed of Eucalyptus urophylla (urophylla), E. pellita (pellita), and clones: GFMO27, I224, and H13. Each genetic material was planted in three experimental plots of 10 lines with sixteen (16) plants/line, in the spacing of tree (3) $\mathrm{m}$ between lines and two (2) $\mathrm{m}$ between plants.

\section{Data collection and analysis}

All trees contained in the useful area of each plot was measured at 24, 36, 48, 60, 72, and 108 months of age, disregarding the trees on the borderline: the circumference at breast height $(\mathrm{CBH})$, later converted to diameter the breast height (DBH) and the total height (h) of all trees.

Based on the number of trees per plot, the number of trees per hectare $(\mathrm{N}$, ha) was estimated. The individual basal area (g) of each tree was calculated based on their DBH and estimated, for hectare, through the sum of the individual basal areas of each plot and extrapolated to a hectare. The total volume of each plot (V) was calculated using a form factor (f) of 0.46 (average form factor calculated based on 50 trees harvested and strictly cubed, from all genetic materials under study, at 60 months old). The canopy area was calculated based on the average canopy diameter of two equidistant diameters measured on the line and between the lines of the field.

The soil of the plots was chemically characterized based on the collection of 12 simple soil samples per plot, in 5 different depths $(0-5 ; 5-10 ; 10-20 ; 20-40$, and 40-60 cm), which was mixed, obtaining four samples composed by field, totaling 60 composite samples, which was collected at 106 months of age from the trees. The soil samples were dried in a circulation oven and renewed air at a temperature of $45^{\circ} \mathrm{C}$ until constant weight, being then manually ground with gral and pistil and sent for laboratory analysis regarding the contents of carbon, organic matter, $\mathrm{pH}$, nitrogen, phosphorus, potassium, calcium, magnesium, and aluminum, based on the methodologies of Tedesco, et al. (1995) and Teixeira, et al. (2017).

At the statistical level, the data were analyzed in a completely randomized design, with the performance evaluation of five genetic materials of Eucalyptus ssp. (treatments), planted in three plots of 160 plants each (sampling units/repetitions), in 10 rows of 16 plants each. Each genetic material is considered as a treatment and each tree a repetition. Due to the mortality that occurred during the 108 months of age of the genetic materials under study, the number of repetitions (trees) per treatment was different.

The data were tabulated in an Excel spreadsheet and later processed in the statistical program $\mathrm{R}$, the main variables being the diameter at breast height, total height, volume with shell, and the canopy area. For data related to soil analysis, the averages and deviations of values between the repetitions were calculated; analysis of variance and comparison test of means between the soil of the different genetic materials was performed.

A correlation matrix between the growth of trees and the average soil quality of the different genetic materials was also calculated, to determine significant direct and inverse relationships between soil quality and tree growth.

\section{Results}

\section{Growth in DBH, height and volume}

The mean DBH values of the genetic materials were compared statistically with each other and between the ages of evaluation (Table 1). In the evaluations carried out at $24,36,48$, and 60 months, only the pellita was statistically inferior to the other four genetic materials, which did not differ from each other. 
Table 1. DBH (cm) growth between the ages of 24 to 108 months in genetic materials from Eucalyptus spp. in the state of Paraná-Brazil.

\begin{tabular}{|c|c|c|c|c|c|c|}
\hline \multirow[t]{2}{*}{ Genetic material } & \multicolumn{6}{|c|}{ Age (months) } \\
\hline & 24 & 36 & 48 & 60 & 72 & 108 \\
\hline H13 & $8.9 \mathrm{~F} \mathrm{a}^{*}$ & $12.7 \mathrm{E} \mathrm{a}$ & $15.7 \mathrm{D}$ a & $17.7 \mathrm{C} \mathrm{a}$ & $21.0 \mathrm{~B} \mathrm{a}$ & $34.0 \mathrm{~A} \mathrm{a}$ \\
\hline Urophylla & $8.0 \mathrm{E} \mathrm{a}$ & $12.8 \mathrm{D} \mathrm{a}$ & $14.8 \mathrm{CD}$ a & $16.6 \mathrm{BC} \mathrm{a}$ & $18.7 \mathrm{~B} \mathrm{ab}$ & $28.8 \mathrm{~A} \mathrm{~b}$ \\
\hline $\mathrm{I} 224$ & $8.8 \mathrm{E} \mathrm{a}$ & $12.3 \mathrm{D} \mathrm{a}$ & $14.7 \mathrm{C} \mathrm{a}$ & $15.0 \mathrm{BC} \mathrm{a}$ & $16.9 \mathrm{~B} \mathrm{~b}$ & $26.5 \mathrm{~A} \mathrm{bc}$ \\
\hline GFMO 27 & $8.4 \mathrm{E} \mathrm{a}$ & $11.6 \mathrm{D} \mathrm{a}$ & $14.3 \mathrm{C} \mathrm{a}$ & $15.0 \mathrm{BC} \mathrm{a}$ & $16.7 \mathrm{~B} \mathrm{~b}$ & $24.5 \mathrm{~A} \mathrm{c}$ \\
\hline Pelitta & $6.1 \mathrm{E} \mathrm{b}$ & $8.4 \mathrm{D} \mathrm{b}$ & 9.7 C Db & $10.3 \mathrm{C} \mathrm{b}$ & $12.2 \mathrm{~B} \mathrm{c}$ & $18.2 \mathrm{~A} \mathrm{~d}$ \\
\hline
\end{tabular}

* averages followed by different letters (lower case in the column and upper case in the row) differ from each other by Tukey's test at 5\% probability of error. Source: Authors.

At 72 months, H13 and urophylla were superior to the others, with clones I224 and GFMO27 showing intermediate behavior and the pellita inferior to all. At 108 months, even greater segregation of genetic materials was noticeable, with an isolated superiority of H13 standing out, followed by urophylla and I224, followed by GFMO27, and, finally, pellita with the lowest DBH.

The genetic materials tested showed an increasing growth with time, with cases of advancement closer to linear (H13), and in other cases with slight stabilization between 48 and 72 months (urophylla), between 60 and 72 months (I224 and GFMO27), and between 48 and 60 months, as in the case of pellita. The data, in general, showed good uniformity, with a coefficient of variation considered low, less than $10 \%$.

Regarding growth in height (Table 2), for the age of 24 months, H13, with $9.1 \mathrm{~m}$, was superior to the others, followed by GFMO27 with $7.8 \mathrm{~m}$, I224 with $6.9 \mathrm{~m}$, and urophylla with $6.9 \mathrm{~m}$, which did not differ from each other and, finally, the pellita, with an average height of $5.5 \mathrm{~m}$. For the age of 36 months, the GFMO27 (14.9 m) obtained superior development, followed by H13 $(12.7 \mathrm{~m})$ and urophylla with $(10.3 \mathrm{~m})$. At this age, the materials with the lowest performance were $\mathrm{I} 224(4.2 \mathrm{~m})$ and pellita $(8.7 \mathrm{~m})$. The lower mean of the pellita at 36 compared to 24 months was due to the fall of some higher trees due to the effect of stronger winds at the time, as well as with other materials between 48 and 60 months.

Table 2. Height growth (m) between 24 and 108 months of age in genetic materials from Eucalyptus spp. planted in ParanáBrazil.

\begin{tabular}{ccccccc}
\hline Genetic material & \multicolumn{5}{c}{ Age (months) } \\
\cline { 2 - 6 } & 24 & 36 & 48 & 60 & 72 & 108 \\
\hline H13 & $9.1 \mathrm{E} \mathrm{a}$ & $12.7 \mathrm{D} \mathrm{b}$ & $15.9 \mathrm{C} \mathrm{a}$ & $15.2 \mathrm{C} \mathrm{a}$ & $20.2 \mathrm{~B} \mathrm{a}$ & $31.9 \mathrm{~A} \mathrm{a}$ \\
Urophylla & $6.9 \mathrm{D} \mathrm{c}$ & $10.3 \mathrm{C} \mathrm{c}$ & $12.2 \mathrm{C} \mathrm{c}$ & $12.3 \mathrm{C} \mathrm{c}$ & $19.7 \mathrm{~B} \mathrm{a}$ & $23.3 \mathrm{~A} \mathrm{~b}$ \\
I224 & $6.9 \mathrm{E} \mathrm{c}$ & $4.2 \mathrm{D} \mathrm{c}$ & $14.1 \mathrm{C} \mathrm{b}$ & $13.6 \mathrm{C} \mathrm{bc}$ & $16.3 \mathrm{~B} \mathrm{~b}$ & $28.7 \mathrm{~A} \mathrm{a}$ \\
GFMO 27 & $7.8 \mathrm{C} \mathrm{b}$ & $14.9 \mathrm{~B} \mathrm{a}$ & $14.8 \mathrm{~B} \mathrm{ab}$ & $13.7 \mathrm{~B} \mathrm{~b}$ & $15.9 \mathrm{~B} \mathrm{~b}$ & $24.8 \mathrm{~A} \mathrm{~b}$ \\
Pelitta & $5.5 \mathrm{E} \mathrm{d}$ & $8.7 \mathrm{D} \mathrm{d}$ & $10.1 \mathrm{C} \mathrm{d}$ & $10.4 \mathrm{C} \mathrm{d}$ & $14.2 \mathrm{~B} \mathrm{c}$ & $18.3 \mathrm{~A} \mathrm{c}$ \\
\hline
\end{tabular}

* averages followed by different letters (lower case in the column and upper case in the row) differ from each other by Tukey's test at 5\% probability of error. Source: Authors. 
At the age of 48 months, H13 and GFMO27 were higher, with an average of $15.9 \mathrm{~m}$ and $14.8 \mathrm{~m}$, respectively. The I224 had $14.1 \mathrm{~m}$, not differing from GFMO27, but differing from H13. Then the urophylla (12.2 m) appeared, followed by the pellita $(10.1 \mathrm{~m})$, which proved to be inferior to all other materials.

At 60 months, H13 and GFMO27 were superior, with an average height of $15.2 \mathrm{~m}$ and $14.8 \mathrm{~m}$, respectively. The I224, with $13.6 \mathrm{~m}$, did not differ from the GFMO27 but differed from H13. The urophylla, with $12.3 \mathrm{~m}$, was superior to the pellita and inferior to the others. The pellita was inferior to all other materials, with an average height of $10.4 \mathrm{~m}$ at this age.

At 72 months of age, H13 and urophylla showed superior growth in height, with $20.3 \mathrm{~m}$ and $19.7 \mathrm{~m}$, respectively, followed by GMFO27 with $15.9 \mathrm{~m}$ and $\mathrm{I} 224$ with $16.3 \mathrm{~m}$; having again the pellita was statistically inferior to all the others, with $14.1 \mathrm{~m}$.

For the 108 months, the height development showed that H13 and I224 were superior, with $31.9 \mathrm{~m}$ and $28.7 \mathrm{~m}$, respectively. GFMO27, with $24.8 \mathrm{~m}$ and urophylla, with $23.3 \mathrm{~m}$ presented intermediate performance and the pellita was inferior, with $18.3 \mathrm{~m}$.

At 24 months of age, the genetic materials that had the highest average growth in volume were H13, I224, and GFMO27, followed by urophylla, which did not differ from GFMO27 and I224 and, finally, pellita (Table 3). For the age of 36 months, H13, GFMO27, in addition to urophylla were superior.

Table 3. Volume growth $\left(\mathrm{m}^{3}\right.$ trees $\left.{ }^{-1}\right)$ between 24 and 108 months of age in genetic materials from Eucalyptus spp. planted in Paraná-Brazil.

\begin{tabular}{lcccccc}
\hline \multirow{2}{*}{ Genetic material } & \multicolumn{5}{c}{ Age (months) } \\
\cline { 2 - 6 } & 24 & 36 & 48 & 60 & 72 & 108 \\
\hline H13 & $0.025 \mathrm{E} \mathrm{a}$ & $0.070 \mathrm{DE} \mathrm{a}$ & $0.134 \mathrm{CD} \mathrm{a}$ & $0.162 \mathrm{C} \mathrm{a}$ & $0.304 \mathrm{~B} \mathrm{a}$ & $1.269 \mathrm{~A} \mathrm{a}$ \\
Urophylla & $0.017 \mathrm{C} \mathrm{b}$ & $0.062 \mathrm{C} \mathrm{a}$ & $0.100 \mathrm{C} \mathrm{b}$ & $0.124 \mathrm{BC} \mathrm{b}$ & $0.250 \mathrm{~B} \mathrm{~b}$ & $0.749 \mathrm{~A} \mathrm{~b}$ \\
I224 & $0.021 \mathrm{C} \mathrm{ab}$ & $0.023 \mathrm{C} \mathrm{b}$ & $0.112 \mathrm{~B} \mathrm{ab}$ & $0.116 \mathrm{~B} \mathrm{~b}$ & $0.177 \mathrm{~B} \mathrm{~b}$ & $0.726 \mathrm{~A} \mathrm{~b}$ \\
GFMO 27 & $0.020 \mathrm{E} \mathrm{ab}$ & $0.070 \mathrm{D} \mathrm{a}$ & $0.109 \mathrm{C} \mathrm{ab}$ & $0.113 \mathrm{C} \mathrm{ab}$ & $0.164 \mathrm{~B} \mathrm{~b}$ & $0.586 \mathrm{~A} \mathrm{~b}$ \\
Pelitta & $0.009 \mathrm{C} \mathrm{c}$ & $0.026 \mathrm{C} \mathrm{b}$ & $0.041 \mathrm{BC} \mathrm{c}$ & $0.049 \mathrm{BC} \mathrm{c}$ & $0.091 \mathrm{~B} \mathrm{c}$ & $0.291 \mathrm{~A} \mathrm{c}$ \\
\hline
\end{tabular}

* averages followed by different letters (lower case in the column and upper case in the row) differ from each other by Tukey's test at 5\% probability of error. Source: Authors.

At 48 months, clone H13, I224, and GFMO27 were the best, but urophylla did not differ from I224 and GFMO27, with pellita as inferior. Clones H13 and GFMO27, at 60 months, showed the greatest development in volume. Urophylla and I224 had intermediate growth but did not differ from GMFO27, with pellita again as inferior. At 72 months, H13 was superior to other genetic materials, followed by clones I224, and GFMO27 and urophylla. The pellita showed, at all ages, to be inferior to all other materials.

\section{Soil chemical quality and its relationship with dendrometric variables}

The interpretations of the chemical quality of the soil were carried out based on Sbcs-Nepar (2017), based on several studies carried out in the state of Paraná, specifically. The soil pH values (Table 4) for the evaluated soil profile, were low in H13, Pellita, and I224 and average for urophylla and GFMO27. The variation with depth was small, with punctual and insignificant differences, with small increases in-depth for urophylla and I224, small decreases for GFMO27 and Pellita, and more constant values for $\mathrm{H} 13$. 
Calcium contents were higher in the superficial layers, decreasing in depth for most genetic materials. Among these, the levels in urophylla are considered high $\left(>4.0 \mathrm{cmolc} / \mathrm{dm}^{3}\right)$ at all depths, followed by GFMO27. In the other genetic materials, an average value $\left(2.1-4.0 \mathrm{cmolc} / \mathrm{dm}^{3}\right)$ of calcium is noted. The Mg presented levels in the soil, considered between high to very high for all genetic materials and all depths of soil. Potassium content in the soil was low to very low $\left(<0.12 \mathrm{cmolc} / \mathrm{dm}^{3}\right)$ in all genetic materials, mainly from $20 \mathrm{~cm}$ deep.

Concerning $\mathrm{Al}^{3+}$, in almost all cases, the values were classified as very low to low $\left(<0.7 \mathrm{cmolc} / \mathrm{dm}^{3}\right)$. The levels of available $\mathrm{P}$ in the soil were average in the first and second layers of soil (less for GFMO27). In the third layer, only the pellita had a medium content and the others between low and very low, variations that also occurred in the fourth and fifth layer of soil (20 to $60 \mathrm{~cm}$ ), but with relatively higher levels and classified between medium and low.

The organic matter of these soils, with corresponding values of available $\mathrm{N}$ and organic carbon, presented contents, in most cases, between medium and high. Only in layers 0-5 cm of H13, 5-10 cm of I224, and 20-40 of I224 and GFMO27 the levels were low.

The CEC (Cation Exchange Capacity) at pH 7.0 showed values between low and medium in all samples analyzed (5$\left.15 \mathrm{cmolc} / \mathrm{dm}^{3}\right)$. About base saturation $(\mathrm{V} \%)$, the values were very high (V\%> 70\%), with an exception being only samples of the layer 20-40 cm from clone I224, which presented a value considered high. 
Table 4. Chemical quality in the different soil depths at 108 months of age for the genetic materials of Eucalyptus spp.

\begin{tabular}{|c|c|c|c|c|c|c|c|c|c|c|c|c|}
\hline \multirow{2}{*}{ Genetic material } & \multirow{2}{*}{$\begin{array}{l}\text { Depth } \\
(\mathrm{cm})\end{array}$} & Al & $\mathbf{C a}$ & Mg & $\mathbf{K}$ & \multirow{2}{*}{$\underset{(\text { Water 1:1) }}{\mathbf{p H}}$} & \multirow{2}{*}{$\underset{\mathrm{mg} \mathrm{dm}}{\mathbf{P}}$} & \multirow{2}{*}{$\frac{\mathbf{N}}{\mathrm{g} \mathrm{kg}^{-1}}$} & \multirow{2}{*}{$\frac{\text { MO }}{\left(\mathrm{g} \mathrm{kg}^{-1}\right)}$} & \multirow{2}{*}{$\frac{\text { CEC }}{\mathrm{pH} 7}$} & \multirow{2}{*}{ V\% } & \multirow[t]{2}{*}{ Al \% } \\
\hline & & \multicolumn{4}{|c|}{ - - - - cmolc/dm³ - - - } & & & & & & & \\
\hline Urophylla & $0-5$ & 0.17 & 4.16 & 1.65 & 0.12 & 5.31 & 4.61 & 1.13 & 22.70 & 7.93 & 74.78 & 2.79 \\
\hline I224 & $0-5$ & 0.25 & 3.95 & 1.62 & 0.08 & 5.08 & 4.44 & 0.93 & 18.50 & 7.67 & 73.66 & 4.24 \\
\hline GFMO27 & $0-5$ & 0.20 & 5.71 & 2.29 & 0.05 & 5.71 & 4.32 & 0.93 & 18.50 & 10.73 & 75.02 & 2.42 \\
\hline Pelitta & $0-5$ & 0.13 & 4.64 & 2.22 & 0.05 & 5.07 & 4.23 & 0.80 & 16.00 & 9.15 & 75.52 & 1.85 \\
\hline $\mathrm{H} 13$ & $0-5$ & 0.30 & 4.97 & 2.16 & 0.04 & 4.77 & 4.67 & 0.52 & 10.30 & 9.71 & 73.84 & 4.02 \\
\hline Urophylla & $5-10$ & 0.13 & 5.67 & 2.37 & 0.09 & 5.22 & 4.14 & 1.24 & 24.70 & 10.74 & 75.70 & 1.57 \\
\hline $\mathrm{I} 224$ & $5-10$ & 0.32 & 3.17 & 1.58 & 0.09 & 4.81 & 4.17 & 0.47 & 9.30 & 6.71 & 72.13 & 6.20 \\
\hline GFMO27 & $5-10$ & 0.20 & 4.76 & 2.10 & 0.08 & 5.61 & 3.67 & 1.39 & 27.70 & 9.28 & 74.78 & 2.80 \\
\hline Pelitta & $5-10$ & 0.15 & 4.63 & 2.19 & 0.08 & 5.37 & 4.65 & 1.65 & 33.00 & 9.17 & 75.25 & 2.13 \\
\hline $\mathrm{H} 13$ & $5-10$ & 0.25 & 3.43 & 1.70 & 0.04 & 4.63 & 4.50 & 1.48 & 29.70 & 7.05 & 73.33 & 4.61 \\
\hline Urophylla & $10-20$ & 0.15 & 4.90 & 2.19 & 0.10 & 5.39 & 2.89 & 1.22 & 24.30 & 9.54 & 75.37 & 2.04 \\
\hline $\mathrm{I} 224$ & $10-20$ & 0.32 & 3.08 & 1.23 & 0.04 & 5.12 & 1.65 & 1.08 & 21.50 & 6.07 & 71.66 & 6.85 \\
\hline GFMO27 & $10-20$ & 0.17 & 4.10 & 1.92 & 0.06 & 5.59 & 1.45 & 0.73 & 14.60 & 8.13 & 74.78 & 2.72 \\
\hline Pelitta & $10-20$ & 0.40 & 2.98 & 1.08 & 0.02 & 4.78 & 5.04 & 1.44 & 28.90 & 5.82 & 70.10 & 8.93 \\
\hline $\mathrm{H} 13$ & $10-20$ & 0.30 & 3.37 & 1.62 & 0.02 & 4.82 & 1.11 & 0.87 & 17.50 & 6.90 & 72.61 & 5.65 \\
\hline Urophylla & $20-40$ & 0.15 & 5.28 & 2.06 & 0.05 & 5.88 & 3.14 & 0.81 & 16.20 & 9.80 & 75.41 & 1.99 \\
\hline $\mathrm{I} 224$ & $20-40$ & 0.80 & 2.09 & 1.16 & 0.07 & 5.11 & 4.32 & 0.66 & 13.10 & 5.36 & 61.94 & 19.42 \\
\hline GFMO27 & $20-40$ & 0.13 & 4.59 & 2.23 & 0.03 & 5.91 & 3.28 & 0.64 & 12.70 & 9.07 & 75.52 & 1.86 \\
\hline Pelitta & $20-40$ & 0.15 & 2.69 & 1.22 & 0.02 & 4.97 & 3.45 & 1.03 & 20.70 & 5.30 & 74.15 & 3.68 \\
\hline H13 & $20-40$ & 0.30 & 3.23 & 1.45 & 0.01 & 4.71 & 2.78 & 1.53 & 30.50 & 6.49 & 72.27 & 6.01 \\
\hline Urophylla & $40-60$ & 0.20 & 4.44 & 1.66 & 0.03 & 5.75 & 4.34 & 0.76 & 15.10 & 8.23 & 74.48 & 3.16 \\
\hline $\mathrm{I} 224$ & $40-60$ & 0.15 & 3.83 & 1.19 & 0.02 & 5.48 & 4.24 & 0.82 & 16.30 & 6.75 & 74.67 & 2.89 \\
\hline GFMO27 & $40-60$ & 0.15 & 3.36 & 1.40 & 0.02 & 5.50 & 3.90 & 1.14 & 22.90 & 6.41 & 74.57 & 3.04 \\
\hline Pelitta & $40-60$ & 0.20 & 2.70 & 1.18 & 0.02 & 5.03 & 4.21 & 0.77 & 15.40 & 5.33 & 73.17 & 4.88 \\
\hline $\mathrm{H} 13$ & $40-60$ & 0.17 & 3.25 & 1.34 & 0.01 & 4.84 & 2.32 & 1.03 & 20.60 & 6.20 & 74.19 & 3.56 \\
\hline
\end{tabular}

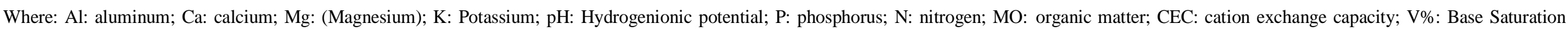
percentage: Al\%: aluminum saturation. Source: Authors. 
With the data of the variables of chemical quality of the soil (contents of $\mathrm{Al}, \mathrm{Ca}, \mathrm{Mg}, \mathrm{N}, \mathrm{MO}, \mathrm{P}, \mathrm{K}$, and $\mathrm{pH}$ value) in the different depths and the dendrometric variables DBH $(\mathrm{cm}), \mathrm{g}\left(\mathrm{m}^{2}\right.$ trees $\left.^{-1}\right), \mathrm{ht}(\mathrm{m}), \mathrm{v}\left(\mathrm{m}^{3} \operatorname{trees}^{-1}\right), \mathrm{hc}(\mathrm{m})$, ac $\left(\mathrm{m}^{2}\right.$ trees $\left.{ }^{-1}\right)$ Pearson correlations were constructed for the studied soil depths. With a focus on correlations between soil quality variables and tree dendrometry, for the depth of $0-5 \mathrm{~cm}$, the correlation analysis showed that there was a positive and significant correlation between $\mathrm{DBH}(\mathrm{cm})$ and $\mathrm{Al}$ content (Table 5). Also, Ca and $\mathrm{Mg}$ correlated positively and $\mathrm{Mg}$ and $\mathrm{K}$ negatively.

For the depth of 5-10 cm, there was a significant inverse correlation between $\mathrm{Ca}$ and $\mathrm{Al}$ and $\mathrm{Mg}$ and $\mathrm{Al}$. There was also a positive correlation between canopy area and volume.

In the $10-20 \mathrm{~cm}$ soil layer, only significant correlations were detected between variables related to soil quality, $\mathrm{N}$ and $\mathrm{P}$, and $\mathrm{MO}$ and $\mathrm{P}$ were positively correlated, and $\mathrm{Al}$ was negatively correlated significantly with $\mathrm{Mg}, \mathrm{K}$, and $\mathrm{pH}$.

From 20 to $40 \mathrm{~cm}, \mathrm{Mg}$ and $\mathrm{pH}$ were significantly correlated, as well as the total height and canopy area. For the last layer of soil, the volume of wood correlated significantly with the content of organic matter and nitrogen in the soil.

Table 5. Pearson's correlation between dendrometric variables and soil chemical attributes at a depth of 0 - 5, 5 - 10, 10 - 20, 20 - 40 and 40 - $60 \mathrm{~cm}$, performed on different genetic materials of Eucalyptus spp., at 108 months old.

\begin{tabular}{|c|c|c|c|c|c|}
\hline Pearson's correlation & $0-5 \mathrm{~cm}$ & $5-10 \mathrm{~cm}$ & $10-20 \mathrm{~cm}$ & $20-40 \mathrm{~cm}$ & $40-60 \mathrm{~cm}$ \\
\hline $\mathrm{Al} \times \mathrm{Ca}$ & - & $-0.9242 *$ & - & - & - \\
\hline $\mathrm{Al} \times \mathrm{Mg}$ & - & $-0.9696 *$ & $-0.9614 *$ & - & - \\
\hline $\mathrm{Al} \times \mathrm{pH}$ & - & - & $-0.8881 *$ & - & - \\
\hline $\mathrm{Al} \times \mathrm{K}$ & - & - & $-0.8734 *$ & - & - \\
\hline $\mathrm{Al} \times \mathrm{DBH}$ & 0.8889* & - & - & - & - \\
\hline $\mathrm{Ca} \times \mathrm{Mg}$ & 0.8753* & - & - & - & - \\
\hline $\mathrm{Mg} \times \mathrm{pH}$ & - & - & - & 0.8791* & - \\
\hline $\mathrm{N} \times \mathrm{P}$ & & & 0.9029* & - & - \\
\hline $\mathrm{N} \times \mathrm{V}$ & - & - & - & - & $0.9501 *$ \\
\hline $\operatorname{Mg} \times \mathrm{K}$ & $-0.8768 *$ & - & - & - & - \\
\hline $\mathrm{MO} \times \mathrm{P}$ & & & 0.9029* & - & - \\
\hline MO x V & - & - & - & - & $0.9501 *$ \\
\hline Ht $\times$ Ac & - & - & - & $0.9580 *$ & - \\
\hline $\mathrm{V} \times \mathrm{Ac}$ & - & $0.8794 *$ & - & - & - \\
\hline
\end{tabular}

Where: *: significative correlation at $5 \%$ of error probability; V: volume $\left(\mathrm{m}^{3}\right.$ tree $\left.^{-1}\right)$; Ac: crown area $\left(\mathrm{m}^{2}\right.$ tree $\left.{ }^{-1}\right)$; $\mathrm{Ht}$ : total height $(\mathrm{m})$; $\mathrm{Al}$ : aluminum; Ca: calcium; Mg: (Magnesium); K: Potassium; pH: Hydrogenionic potential; P: phosphorus; N: nitrogen; MO: organic matter. Source: Authors.

\section{Discussion}

In a comparative study, Ferreira, et al. (2017) studied the growth and production of Eucalyptus species in the Médio Paraíba do Sul-RJ Region, including Eucalyptus grandis, E. pellita, E. saligna, and E. urophylla and the hybrid Eucalyptus urophylla x E. grandis. E. pellita, at 18 months, had a DBH of $3.7 \mathrm{~cm}$ and, at 80 months, of $10.1 \mathrm{~cm}$. The hybrid of Eucalyptus urophylla x E. grandis presented, for 18 and 80 months, 5.3 and $14.4 \mathrm{~cm}$ of DBH, demonstrating the superior capacity that the hybrid has of growth in relation to the seminal stand. Apparently, E. pellita presented a good relative performance, neither in Paraná nor in Rio de Janeiro.

Santos, et al. (2013) tested the adaptability of several Eucalyptus sp. in Rio Grande do Sul, emphasizing that interspecific hybrids involving a three-way cross species have greater adaptability and stability to different edaphoclimatic conditions. Thus, 
thinking about the edaphoclimatic conditions, one can select species with adaptive characteristics already known: E. grandis (growth), E. benthamii (frost resistance), E. kirtoniana (water resistance), E. urophylla (rooting), E. camaldulensis (resistance to water deficit). This study suggests that, when the degree of improvement of genetic materials improves, the growth response is more pronounced in relation to seminal materials, provided that their silviculture requirements are satisfied, at least at basic levels.

In the state of Rio Grande do Sul, Beltrame, et al. (2012), performed a clonal test of interspecific hybrids of Eucalyptus urophylla, E. globulus, E. maidenii, E. saligna, E. grandis, E. pellita, E. resinifera, E. kirtoniana, and E. dunnii, generators of 138 clones. Forest inventories at 3 and 7 years of age made it possible to divide the results into five groups, with mean DBH, at three years of age, of $14.8 \mathrm{~cm}$ (first group), $13.8 \mathrm{~cm}$ (second group), $12.9 \mathrm{~cm}$ (third group), $12.1 \mathrm{~cm}$ (fourth group) and $10.9 \mathrm{~cm}$ (fifth group) and, at 7 years, in the same sequence, $24.7 \mathrm{~cm}, 21.4 \mathrm{~cm}, 17.9 \mathrm{~cm}, 14.7 \mathrm{~cm}$ and $12.3 \mathrm{~cm}$.

In the state of Rio de Janeiro, at 18 months of age, Eucalyptus urograndis, E. grandis, and E. urophylla were the genetic materials that showed the best establishment and growth for the region's edaphoclimatic conditions. Corymbia citriodora was the species that had the lowest survival rate and the lowest growth (Queiroz, et al., 2009).

In terms of DBH, it can be considered that hybrid and clonal genetic materials, as well as E. urophylla, which are part of the referred clones, present superiority in growth, in contrast to E. pellita, which was inferior to the other materials.

For height growth, Queiroz, et al. (2009), in a study with species of Eucalyptus, found, for 6 and 18 months of age, higher growth of E. urophylla, E. urograndis, and E. grandis with 2.3; 2.1 and 2.0 and 6.3; 5.7 and 6.1 meters in height at 6 and 18 months and E. citriodora was the species with the lowest height, in the two evaluation periods. The E. camaldulensis plants, with $5.2 \mathrm{~m}$, were also in the group of the species with the highest growth at six months, but at 18 months, they showed growth in the group of intermediate growth species, together with E. saligna $(5.2 \mathrm{~m})$ and E. pellita $(4.6 \mathrm{~m})$.

In a study of productivity and economic evaluation of crop-livestock-forest integration systems (ILPF), in Campo Grande - MS, the height did not show any difference between the tested spacing, with the clonal hybrid E. urophylla $\mathrm{x}$ E. grandis (clone H13), with $20.7 \mathrm{~m}$ for the spacing in ILPF of $14 \mathrm{~m} \mathrm{x} 2 \mathrm{~m}$, and in ILPF with $22 \mathrm{~m} \mathrm{x} 2 \mathrm{~m}$, being $21.6 \mathrm{~m}$, at 8 years of age (Abrantes, et al., 2019).

Ferreira, et al. (2017) studied the growth and production of Eucalyptus grandis, E. pellita, E. saligna, and E. urophylla and the hybrid Eucalyptus urophylla $\times$ E. grandis. The results showed that the hybrid E. urophylla $\mathrm{x}$ E. grandis showed greater growth in height, both at 18 months $(6.7 \mathrm{~m})$ and at 80 months $(23.5 \mathrm{~m})$. E. pellita, on the other hand, showed the lowest growth, with $4.6 \mathrm{~m}$ at 18 months and $16.7 \mathrm{~m}$ at 80 months.

In the state of Mato Grosso, the H13 hybrid also showed higher productivity, but this was variable between different study sites evaluated (Miranda, et al., 2019). This demonstrates the importance of assessing the adaptive capacity of hybrids to local edaphoclimatic conditions, before recommending it for commercial plantations, as it can respond differently even in different regions of the same state.

In a study comparing the silviculture performance of eucalyptus clones in ILPF, it were found that clone GG100 had the lowest values of basal area, and volume per plant and clone I144 stood out for its high productivity, with $25 \%$ volume per hectare more than the others. Clone I144 showed good levels of adaptation and productivity to environmental conditions. Thus, the use of this clone in commercial plantations should provide good levels of productivity, provided that appropriate silviculture techniques are applied (Reis, et al., 2014).

Ferreira, et al. (2017), in his study of growth and production of Eucalyptus spp. in the Médio Paraíba do Sul Region, state of Rio de Janeiro, the species used were Eucalyptus grandis, E. pellita, E. saligna and E. urophylla, from Anhembi-SP, level of improvement of seed production area (SPA) F1, and also the hybrid Eucalyptus urophylla $\mathrm{x}$ E. grandis, from Itirapina- 
SP. E. pellita, at 80 months, had a volume of $0.08 \mathrm{~m}^{3} /$ tree and the hybrid of Eucalyptus urophylla $\mathrm{x}$ E. grandis had a volume of $0.15 \mathrm{~m}^{3} /$ tree, practically double the production of the first.

As for the chemical quality of the soil, according to Tomé Jr. (1997), in general, under natural conditions, acidity increases as it deepens in the soil due to nutrients that decrease its contents. In soils under forest, the release of nutrients by the litter will interfere with the $\mathrm{pH}$ values, mainly in the superficial layers due to the accumulation of organic matter, generally with higher $\mathrm{pH}$ values on the surface.

For the production of Eucalyptus spp., the ideal $\mathrm{pH}$ for cultivation is 5 to 5.5 and, if it is below this range, correctives should be applied. By increasing the $\mathrm{pH}$, it is possible to increase the availability of nutrients to be absorbed by plants (Santos, et al., 2018).

Everything indicates that clone $\mathrm{H} 13$ has a good adaptation to soils with greater acidity, as it showed higher growth values and, in the plots where it was planted, it was exactly where the lowest $\mathrm{pH}$ values were found.

According to Paraná's fertilization and liming manual (Sbcs-Nepar, 2017), liming is recommended when the soil is very acidic ( $\mathrm{pH}<5.0)$ or when it has low $\mathrm{Ca}$ and $\mathrm{Mg}$ contents.

Aluminum is toxic to plants, but Eucalyptus spp., species are considered to have great adaptability and resistance to acidic soils with a high aluminum content, showing that their growth happens despite the soil having this characteristic (SbcsNepar, 2017).

Soils that have high acidity and high aluminum content will proportionally have $\mathrm{Ca}$ and $\mathrm{Mg}$ with low levels (SbcsNepar, 2017). The aluminum in the soil, in neutral conditions, has its solubility practically negligible, however, in acidic soils with $\mathrm{pH}$ below 5.0, as happened in clone $\mathrm{H} 13$, in all depths, and also in I224 $(5-10 \mathrm{~cm})$, its solubility increases rapidly and a part of the soil CTC can be occupied by this element, replacing $\mathrm{Ca}, \mathrm{Mg}$ and $\mathrm{K}$. The exchangeable $\mathrm{Al}\left(\mathrm{Al}^{3+}\right)$ is in equilibrium with the $\mathrm{Al}^{3+}$ of the soil solution, a condition in which it can be hydrolyzed and release $\mathrm{H}^{+}$ions, which reduces the $\mathrm{pH}$, that is, increases the acidity of the soil, compromising the absorption other elements (Barros, et al., 2005).

In the superficial layer of soil $(0-5 \mathrm{~cm})$, the significant positive correction between $\mathrm{Al}$ content in the soil and growth in DBH stands out. This situation shows that, despite the relatively higher levels of some genetic materials in the soil, such as clone H13, such content was not sufficient to compromise growth in DBH. Malavolta (2006), citing other authors, reports that Al, in low concentrations, can be beneficial to the growth of eucalyptus, possibly due to the increase in the availability of $\mathrm{P}$ and $\mathrm{Fe}$, due to the lowering of the $\mathrm{pH}$, a consequence of the hydrolysis of $\mathrm{Al}$, as well as the precipitation of excess $\mathrm{P}$ and blocking negative charges on the cell wall, which would facilitate the absorption of $\mathrm{H}_{2} \mathrm{PO}_{4}$.

Despite this, in the vast majority of scientific studies that address the theme, $\mathrm{Al}$ is considered as toxic to eucalyptus in general, however, it is important to understand that this phenomenon is certainly significant, but at high levels $\left(>1.6 \mathrm{cmolc} / \mathrm{cm}^{3}\right)$ (Sbcs-Nepar, 2017).

This situation also explains the significantly negative correlations between $\mathrm{Al}$ with $\mathrm{Ca}, \mathrm{Mg}, \mathrm{K}$, and $\mathrm{pH}$, since if there are elevations of $\mathrm{Al}$ levels in the soil, consequently it will occupy more space in the CEC compared to other elements like Ca, $\mathrm{Mg}$, and K, decreasing the $\mathrm{pH}$ value and occurring competitive inhibition in the absorption of nutrients (Tomé Jr., 1997; (Faquin, 2005). Under these conditions, the expected relations between $\mathrm{Mg}$ and $\mathrm{K}$, negative, can also be emphasized, since these elements compete by the same binding sites on the ground (White, 2009).

As a final highlight of the approach, the influence of the organic matter and nitrogen content of the soil with the volume of wood from the tested Eucalyptus genetic materials denotes the importance of this fraction of the soil for maintaining its quality and the consequent productivity of the eucalyptus plantations. In the specific case of $\mathrm{N}$, a macronutrient essential for plants, as part of the composition of chlorophyll, it participates directly in photosynthesis, also playing, among other roles, that of increasing the protein content in plants (Souza \& Lobato, 2004). 
In addition to providing various nutrients to plants, through the process of mineralization of organic matter, $\mathrm{N}$ is extremely important in the growth of eucalyptus. In low fertility soil, in the Cerrado region of Minas Gerais, Jesus, et al. (2012), when evaluating doses and sources of nitrogen in the productivity of eucalyptus and fractions of organic matter, observed that the dose of $154 \mathrm{~kg} \mathrm{ha}^{-1}$ of $\mathrm{N}$ in the form of ammonium sulfate, at 30 months of age, provided the volume maximum $95.2 \mathrm{~m}^{3} \mathrm{ha}^{-}$ 1 .

Because of these facts, good nutritional management of eucalyptus plantations is essential, to obtain high yields, and, in most cases, the application of fertilizers is necessary (Barros, et al., 2005).

\section{Conclusion}

The genetic material highlighted in growth was clone H13, with values higher than the other materials, in all variables analyzed, reaching an individual volume of $1.27 \mathrm{~m}^{3}$ at 108 months of age.

The variation in the growth of genetic materials at different ages of the evaluation was shown to be uniform, with clone H13 being superior in all evaluations and E. pellita inferior in all measurements. The other genetic materials (GFMO27, I244 and E. urophylla) showed to be variable in their growth behavior at different ages of evaluation, but not exceeding the above and lower materials mentioned.

The soil quality in the experimental area was shown to be medium to high, with some cases of higher acidity, but with good levels of nutrients and low levels of Al. The most acidic soil was found when planting H13; even so, this material was the one that showed the best growth and adaptation to this condition.

The edaphic variables most influential in the growth of the genetic materials of Eucalyptus spp. were the contents of $\mathrm{Al}, \mathrm{N}$, and organic matter, in a directly proportional way.

The genetic materials recommended for planting in new regionalized tests and on an operational scale are, in sequence, clone $\mathrm{H} 13$ and E. urophylla, also having the possibility of recommending clones GFMO27 and I244, which also have high growth, despite lower than the first. E. pellita did not show satisfactory growth in Dois Vizinhos region, and its planting is not recommended.

Based on the results obtained on an experimental scale, it can be considered that clonal genetic materials tend to show good growth in the region, especially clone H13, from the hybrid E. urograndis.

It's necessary to expand the tests, to these and another genetic material in small farms scale, to expand the representativity of the results and applying the forestry results in the agricultural sector. The monitoring of the growth, soil quality and the relations soil x plant it's always necessary.

\section{Acknowledgments}

To the CAPES (Coordination of Superior Level Staff Improvement) for supporting the UTFPR Graduate Program in Agroecosystems (PPGSIS). To the Forest Science Department of Luiz de Queiroz College of Agriculture - University of Sao Paulo for the supply of the genetic material of Eucalyptus.

\section{References}

Abrantes, K. K. B., Paiva, L. M., Almeida, R. G. De, Urbano, E., Ferreira, A. D. \& Mazucheli, J. (2019). Modeling the individual height and volume of two integrated crop-livestock-forest systems of Eucalyptus spp. in the Brazilian Savannah. Acta Scientiarum - Agronomy, 41(e42626). 10.4025/actasciagron.v41i1.42626.

Alvares, C. A., Stape, J. L., Sentelhas, P. C., Gonçalves, J. L. de M. \& Sparovek, G. (2013). Köppen's climate classification map for Brazil. Meteorologische Zeitschrift, 22(6), 711-28. 10.1127/0941-2948/2013/0507. 
Assis, T. F., Abad, J. I. M. \& Aguiar, A. M. (2015). Melhoramento Genético do Eucalipto. In: M. V. Schumacher \& M. Viera (Eds.). Silvicultura do eucalipto no Brasil (pp. 225-47). UFSM.

Barros, N. F., Neves, J. C. L. \& Novais, R. F. (2005). Fertilidade de solos, nutrientes e produção florestal. Visão Agrícola, 4, 76-9. https://www.esalq.usp.br/visaoagricola/sites/default/files/va04-florestas-plantadas06.pdf.

Beltrame, R., Bisognin, D. A., Mattos, B. D., Cargnelutti Filho, A., Haselein, C. R., Gatto, D. A. \& Santos, G. A. dos. (2012). Desempenho silvicultural e seleção precoce de clones de híbridos de eucalipto. Pesquisa Agropecuária Brasileira, 47(6), 791-6. 10.1590/S0100-204X2012000600009.

Embrapa (2018). Sistema brasileiro de classificação de solos. Brasília: Empresa Brasileira de Pesquisa Agropecuária.

Faquin, V. (2005). Nutrição Mineral De Plantas. UFLA.

Ferreira, D. H. A. A. D., Leles, P. S. dos S., Oliveira Neto, S. N. de, Paula, T. R., Coutinho, R. P. \& Silva, R. L. da. (2017). Crescimento e Produção de Eucalipto na Região do Médio Paraíba do Sul, RJ. Floresta e Ambiente, 24, e131315. 10.1590/2179-8087.131315.

Higa, R. C. V. \& Wrege, M. S. (2010). Zoneamento climático de Eucalyptus grandis para a região Sul do Brasil. Colombo: Embrapa Florestas (Documentos, 209).

IBÁ - Indústria Brasileira de árvores (2020). Relatório Anual. - Indústria Brasileira de árvores. https://iba.org/datafiles/publicacoes/relatorios/relatorio-iba2020.pdf.

Imaña-Encinas, J. \& Santana, O. A. (2019). O trabalho científico na metodologia científica. Universidade de Brasília (UnB).

Jesus, G. L. de, Barros, N. F. de, Silva, I. R. da, Neves, J. C. L., Henriques, E. P., Lima, V. C., Fernandez, L. V., Soares \& E. M. B. (2012). Doses e Fontes de Nitrogênio na Produtividade do Eucalipto e nas Frações da Matéria Orgânica em Solo da Região do Cerrado de Minas Gerais. Revista Brasileira de Ciência do Solo, 36(1), 201-214. 10.1590/S0100-06832012000100021.

Miranda, D. L. C., Lisboa, G. S., Silva, F. da., Sanquetta, C. R., Dalla Corte, A. P. \& Condé, T.M. (2019). Crescimento de híbridos de eucalipto no estado de Mato Grosso. Advances in Forestry Science, 6(2), 617-621. https://doi.org/10.34062/afs.v6i2.7360

Pincelli, A. L. P. S. M., Seixas, F. \& Nunes, R. (2014). Compactação e fertilidade do solo após colheita do eucalipto utilizando feller buncher e skidder. Cerne, 20(2), 191-198. 10.1590/01047760.201420021414.

Queiroz, M. M., Leles, P. S. dos S., Oliveira Neto, S. N. \& Ferreira, M. A. (2009). Comportamento de materiais genéticos de eucalipto em Paty do Alferes, RJ.. Floresta e Ambiente, 16(1), 1-10. Retrieved from https://www.floram.org/article/588e221be710ab87018b465f.

Reis, C. A. F. T., Santos, P. E. T. dos \& Paludzyszyn Filho, E. (2014). Avaliação de clones de eucalipto em Ponta Porã, Mato Grosso do Sul. Brazilian Journal of Forestry Research, 34(80), 263-269. 10.4336/2014.pfb.34.80.569.

Ribeiro, R. R. (2013). Status nutricional de diferentes materiais genéticos de Eucalyptus sp. plantados em Dois Vizinhos-PR. (Trabalho de Conclusão de Curso em Engenharia Florestal, Universidade Tecnológica Federal do Paraná. Repositório Institucional da UTFPR. http://repositorio.utfpr.edu.br/jspui/handle/1/11004.

Santos, G. A., Resende, M. D. V., Silva, L. D., Higa, A. R. \& Assis, T. F. (2013). Adaptabilidade de híbridos multiespécies de eucalyptus ao estado do Rio Grande do Sul. Revista Árvore, 37(4), 759-769. 10.1590/S0100-67622013000400019.

Schumacher, M. V. \& Viera, M. (2015). Silvicultura do eucalipto no Brasil. UFSM.

Serpe, E. L., Motta, A.C.V., Figueiredo Filho, A. \& Arce, J. E. (2018). Efeitos de diferentes dosagens de adubação no crescimento inicial de Eucalyptus benthamii Maiden et Cambage. Biofix Scientific Journal, 1(1), 204-9. http://dx.doi.org/10.5380/biofix.v3i1.58444.

Sociedade Brasileira De Ciência Do Solo - Núcleo Estadual Paraná (2017). Manual de adubação e calagem para o estado do Paraná. SBCS/NEPAR.

Souza, D. M. G. \& Lobato, E. (2004). Cerrado correção e adubação do solo. Embrapa.

Tedesco, M. J., Gianello, C., Bissani, C. A., Bohnen, H. \& Volkweiss, S. J. (1995). Análises de solo, plantas e outros materiais. UFRGS.

Teixeira, P. C., Donagemma, G. K., Fontana, A. \& Teixeira, W. G. (2017). Manual de métodos de análise de solo. Embrapa.

Tomé Júnior, J. B. (1997). Manual para interpretação de análise de solo. Agropecuária.

White, R. E. (2009). Princípios e práticas da ciência do solo. Andrei.

Wink, C., Lange, A., Araújo, K. Z., Almeida, A. P. S. de; Behling, M. \& Wruck, F. J. (2018). Biomassa e nutrientes de eucalipto cultivado em sistema agrossilvipastoril. Nativa, 6(especial), 754-62. 10.31413/nativa.v6i0.5987. 